Participatory Educational Research (PER)

Special Issue 2016-I, pp., 63-71; 01 January, 2016

Available online at http://www.partedres.com

ISSN: 2148-6123

http://dx.doi.org/10.17275/per.16.spi.1.8

\title{
An Investigation into Medical Students' English Language Needs
}

\author{
Mustafa Naci KAYAOĞLU and Raşide DAĞ AKBAŞ* \\ Department of English Language and Literature, Karadeniz Technical University, Trabzon, \\ Turkey
}

\begin{abstract}
Due to the acceptance of English in twentieth century as international language of science and medicine, a considerable body of medical research and literature has been produced in English. This dominance of English in medical accounts paves the way for emergence of a new ESP branch (English for Specific Purposes) as EMP (English for Medical Purposes). The basic insight into this trend is to offer course design, content and materials by being responsive to target language learners' own agenda. Therefore, it is necessary to find out first what is specifically appropriate, available and applicable for the target situation and target language learners in terms of their needs. In discovering their needs, needs analysis is regarded as an integral part of decision making processes in EMP. Without conducting a needs analysis process, using a medical English course book might not be enough for a medical student studying in an EFL (English as a Foreign Language) context like Turkey since most of the medical English course books in use are mostly addressing the needs of students in an ESL (English as a Second Language) context. Accordingly, as a part of a needs analysis process, this study aims to investigate academic English language needs of first year medical students who are attending advanced English course at the Faculty of Medicine at Karadeniz Technical University. The data was collected via a structured questionnaire with 47 items. It covers five different parts focusing on medical students' purposes of learning English, significance of learning English, their preference of learning environment, language learning needs of major language skills (reading, writing, speaking, listening), their preference of assessment type. The questionnaire was administered to 169 students at the Faculty of Medicine at Karadeniz Technical University. Descriptive statistics was employed in order to analyze the data.
\end{abstract}

Keywords: English language teaching; English for medical purposes; language needs; needs analysis

\section{EGP, ESP and EMP}

Regardless of their departments and also their future professions they are studying, most of the students are taught General English (GE or English for General Purposes, EGP) in many universities. In such an approach to language education, students' individual differences, needs, wishes, interests and goals are mostly neglected by the authorities including administration and lecturers. With an awareness of such problems in language education, English for Specific Purposes (ESP) arose as a key solution in 1960s (Hutchinson and Waters, 1987; Johns, 2013; Master, 2005). The basic insight into this trend is to offer

\footnotetext{
* Corresponding e-mail: raside@ktu.edu.tr
} 
course design, content and materials by being responsive to target language learners' own agenda. Therefore, it is necessary to find out first what is specifically appropriate, available and applicable for the target situation and target language learners in terms of their needs.

In time, different reasons such as demands of a fast changing world resulted in emergence of different ESP branches. Due to the acceptance of English in twentieth century as international language of science and medicine, a considerable body of medical research and literature has been produced in English. This dominance of English in medical accounts paves the way for emergence of a new ESP branch as EMP (English for Medical Purposes). Most of the EMP research emphasizes on the importance of intra-professional communication, spoken interactions in conferences or medical discourse communities (Master, 2005) and written medical genres including case reports, letters of referral etc (Ferguson, 2013). Similarly, doctor-patient communication skills are particularly at the heart of the field (Basturkmen, 2010).

\section{Needs Analysis}

In discovering students' needs, needs analysis is regarded as an integral part of decision making processes before designing a course. Accordingly, needs analysis process is considered as an attempt to answer questions regarding when, where, and why language learners need target language (Basturkmen 2010). Begining with Munby's communicative needs processor in 1978, meanings of needs or types of needs are still matter of discussion in related literature (Basturkmen, 2010). Addressing all these issues, Dudley-Evans and John (1998, p.125) presents a comprehensive framework of needs analysis:

A. professional information about the learners: the tasks and activities learners are/will be using for - target situation analysis and objective needs

B. personal information about the learners: factors which may affect the way they learn such as previous learning experiences, cultural information, reasons for attending the course and expectation of it, attitude to English - wants, means, subjective needs

C. English language information about the learners: what their current skills and language use are - present situation analysis - which allow us to assess (D)

D. the learners' lacks: the gaps between $(\mathrm{C})$ and $(\mathrm{A})$ - lacks

E. language learning information: effective ways of learning the skills and language in (D) - learning needs

F. professional communication information about (A): knowledge of how language and skills are used in the target situation - linguistic analysis, discourse analysis, genre analysis

G. what is wanted from the course

H. information about the environment in which the course will be run - means analysis

\section{How to conduct a needs analysis and how to collect the data?}

For a comprehensive needs analysis, there are many data gathering instruments and sources from which data is collected in the related literature. The necessary data during the needs analysis process is collected via some data gathering instruments including "questionnaires, analysis of authentic spoken and written texts, discussions, structured interviews, observations and assessments including formal or informal judgements of learners' performance or progress" and from "the learners, people working or studying in the field, ex-students, documents relevant to the field, clients, employers, colleagues, ESP research field" (Dudley-Evans and John, 1998, p.132). So as to lead an effective needs 
analysis process, it is also important to note that it should be an ongoing process in that it should be employed not only to design a course but also to improve an ongoing ESP course (Basturkmen, 2010; Dudley-Evans and John, 1998).

\section{Related Research}

In Turkey, most of the research in ESP field focuses on needs analysis process See (Diken, 2006; Hergüner, 1990; Kaygan, 2005; Kazar, 2013; Önder, 2012; Sabuncuoğlu, 2010; Seçen, 2001; Solak, 2012; Taşç1 2007; Üstünlüoğlu, 1994; Yeniçeri, 2008). When it comes to EMP, some of the related research indicate that the classrooms with EGP orientation do not meet medical students' needs (Önder, 2012; Sarı, 2003; Taşç1, 2007; Yeniçeri, 2008). There are also some research on EMP field which analyzes needs and accordingly suggest new course designs accordingly (Akgül, 1991; Alagözlü, 1994; Boztaş, 1987; Ertaş, 1998). In most of these studies, students' needs were collected via questionnaires and interviews. Additionally, Önder (2012) made use of observations and journal keeping as a part of ethnography in conducting needs analysis. They propose that teaching medical terminology, reading and translation should be emphasized in such courses. Ertaş (1998) suggests a skillsbased modular course design while Boztaş (1987) recommend to conduct medical English courses designed with student-centered approach and communicative language teaching method.

\section{Methodology}

\section{Purpose of the study}

As a part of a needs analysis process, this study aims to investigate academic English language needs of first year medical students who are attending advanced English course at the Faculty of Medicine at Karadeniz Technical University.

\section{Nature of the study}

The current study is adescriptive case study (Yin, 1994) in nature since it describes academic language needs ofstudents at a specific department of Karadeniz Technical University.To this end, it employs quantitative method since the data is collected via a structured questionnaire.

\section{Data Collection Instrument}

A structured questionnaire with 47 items was used in this study. The questionnaire was prepared in the light of two experts' opinion in the field of teaching English as foreign language after conducting a comprehensive literature review on the related topic. The first draft questionnaire was piloted with a similar sample of 20 medical faculty students. According to their feedback and the experts' opinion, it was corrected and reorganized. Thelatest version of structured questionnaire covers six different themesand varied number of items as follows: on medical students' purposes of learning English (7 items), significance of learning English (3 items), their preference of learning environment (5 items), significance order of major language skills (4 items), language learning needs regarding major language skills (reading-7 items, writing- 8 items, speaking- 6 items, listening- 6 items), their preference of assessment type. The part of language learning needs regarding major language skills was adapted from a similar study by Gessesse (2009).Except for a multiple-choice question on the participants'preference of assessment type and a rank order scaling type of question on the 
significance order of major language skills, the entire questionnaire employed five-point Likert format.

\section{Data Collection Procedure}

In order to collect the data at the faculty, the researchers asked permission from the faculty administration. Following this permission, the structured questionnaire was administered to 169 medical faculty students who were volunteer to attend this study. It was conducted face to face and in paper. It lasted approximately 15 minutes.

\section{Reliability, Validity and Ethical Considerations in Research}

So as to ensure the validity of the research, a comprehensive literature review was conducted before preparing the data collection instrument. Expert opinion was also obtained. It is important to note that the part devoted to major language skills part was adapted from Gessesse (2009) since the study was conducted with a similar purpose and sample. Additionally, "other" section was included so that the participants could declare their own ideas on the related issue. Following the piloting of the instruments with a similar sample, reliability of the questionnaire was checked by using SPSS 16.0. The overall results indicated that the Cronbach's Alpha measure for all of the parts was .91 which is quite satisfactory. As for ethical issues, the study was voluntary basis and the participants were informed about the purpose of the study and process before the data collection process. That is, their consent was taken before conducting the questionnaire.

\section{Data Analysis Procedure}

In line with the purpose of the study, the data was analysed quantitatively. Descriptive statistics was mainly conducted. Because of the nature of the questionnaire items, while the part on the participants'preference of assessment type was analyzed with frequency and percentages, mean and standard deviation was employed for the rest of the questionnaire.

\section{Findings and Discussion}

In this section, the related findings are discussed in relation with different parts of the questionnaire which are presented in the tables. The first table presents the medical student's purposes of learning English.

Table 1. Medical Students' Purposes of Learning English

\begin{tabular}{lll}
\hline Purposes & Mean & SD \\
\hline Interact with people & 4.26 & 1.06 \\
Study on medical resources & 4.02 & 1.13 \\
Perform activities in my field & 4.05 & 1.05 \\
Write medical reports/papers & 3.59 & 1.27 \\
Attend any academic context (conference, meeting with professionals etc.) & 3.72 & 1.23 \\
Correspond with English speaking professionals in the field & 4.03 & 1.04 \\
Achieve a sufficient score on language exams in the field & 4.11 & 1.18 \\
\hline
\end{tabular}

Total $(N=169)$

As presented in the table 1, the participants are in the opinion that they mostly learn English since they want to interact with people, to achieve a sufficient score on language exams in the medical field. The mean scores indicate that performing related activities in their field, corresponding with English speaking professionals in the field and studying on medical resources are also among the most significant purposes of learning English. 
Table 2. Importance of Learning English

\begin{tabular}{lll}
\hline How important English learning is for you? & Mean & SD \\
\hline As an individual & 4.16 & 1.02 \\
As a medical student & 3.90 & 1.04 \\
As a prospective medical doctor & 4.27 & .92 \\
\hline Total $(N=169)$ & &
\end{tabular}

In the second part of the questionnaire, the participants were asked how important to learn English in accordance with their different roles in life on a five Likert scale ranging from the least important (1) to the most important (5). The responses to the items show that the participant medical students regard English important because they will be doctor in the future. This finding implies that they consider English as a part of their future professional life much more important than a part of being medical student.

Table 3. Preference of Learning Environment

\begin{tabular}{lll}
\hline Which learning environment do you prefer for English courses? & Mean & SD \\
\hline Traditional classroom (Face to face teaching) & 3.56 & 1.23 \\
Blended learning (both face to face and online learning) & 3.24 & 1.27 \\
Online classroom & 2.84 & 1.29 \\
Synchronous distance learning & 2.52 & 1.28 \\
Asynchronous distance learning & 2.73 & 1.50 \\
\hline Total $(N=169)$ & \\
\hline
\end{tabular}

Learning environment was another theme in the questionnaire as presented in the table 3 . The participants were asked which learning environment do you would prefer for English courses on a five Likert scale ranging from very undesirable (1) to very desirable (5). The mean values in the table 3 indicates that they prefer traditional classroom or blended learning. This finding suggest that they seem to be negative or have some concerns about online or virtual learning environments.

In the following table, the findings regarding the significance order of major language skills are presented.

Table 4. The Significance Order of Major Language Skills

\begin{tabular}{lll}
\hline Major Language Skills & Mean & SD \\
\hline Speaking & 3.30 & 1.11 \\
Listening & 2.72 & 1.07 \\
Reading & 2.67 & 1.11 \\
Writing & 2.46 & 1.12 \\
\hline Total $(N=169)$ & & \\
\hline
\end{tabular}

The participants were asked to order major language skills on a rank order scaling type of question ranging from not very important (1) to very important (4). The findings indicate that speaking is the most important skills for the participants and it is followed by listening, reading and writing respectively. This finding presented in the table 4 is in line with the finding as presented in the table 2 that they mainly see English as a part of their future profession since they probably think that getting contact with patient and other professionals is important part of their profession.

The following tables are about how important to improve major language skills for the participants. Each finding regarding the major language skills are presented in different tables with the items about the related sub-skills. All the items of the questionnaire presented in the following tables were asked on a five Likert type ranging from the least important (1) to the 
most important (5).

Table 5. The importance of Improving Reading Skill

\begin{tabular}{lll}
\hline Reading Sub-Skills & Mean & SD \\
\hline Reading technical articles in medical field & 4.05 & 1.03 \\
Reading manuals in my study & 4.00 & 1.07 \\
Reading instructions of assignments and projects & 3.77 & 1.11 \\
Reading laboratory instructions & 3.55 & 1.20 \\
Reading study notes of the courses & 3.94 & 1.07 \\
Reading medical books & 4.18 & .99 \\
Reading general books & 3.69 & 1.18 \\
\hline Total $(N=169)$ & & \\
\hline
\end{tabular}

As shown in the table 5, to read technical books, articles and manuals in medical field are more important reading sub-skills for the participants as compared with to read instructions or class notes. These findings may be attributed to the fact that the participants study at a Turkish-medium medical faculty. If they studied at a totally English-medium medical faculty, they would give much more importance to in-class reading sub-skills such as reading laboratory instructions.

Table 6. The importance of Improving Writing Skill

\begin{tabular}{lcc}
\hline Writing Sub-Skills & Mean & SD \\
\hline Writing prescriptions & 3.34 & 11.34 \\
Writing lab reports & 3.79 & 1.25 \\
Writing projects on medicine & 3.85 & 1.22 \\
Writing articles on medicine & 3.72 & 1.20 \\
Note making from written sources & 3.56 & 1.20 \\
Writing apprenticeships reports & 3.39 & 1.22 \\
Writing assignments & 3.36 & 1.24 \\
Answering questions on exam & & 1.30 \\
\hline Total $(N=169)$ & \\
\hline
\end{tabular}

As the mean values presented in the table 6 show that writing articles, projects and notetaking from the written sources are among the most important writing sub-skills for the participant medical students. Since they maybe study at a Turkish context, they do not give much importance to write prescriptions or laboratory reports in English as inferred from the low mean values in the table 6.

Table 7. The importance of Improving Listening Skill

\begin{tabular}{lll}
\hline Listening Sub-Skills & Mean & SD \\
\hline Listening to lecture & 3.42 & 1.22 \\
Listening to oral presentations & 3.79 & 1.18 \\
Listening to instructions for exams & 3.42 & 1.23 \\
Listening to medical audio \& video sources & 4.11 & 1.05 \\
Listening to medical conversations & 4.09 & 1.06 \\
Listening to other audio sources & 3.63 & 1.18 \\
\hline Total $(N=169)$ & & \\
\hline
\end{tabular}

As the mean values in the table 7 point out, the participants give more importance to listen medical audio-video sources, medical conversations and oral presentations in English. These fiindings are also in line with the findings presented in table 2 showing that the participants mostly learn English since they plan to use it in their future profession, probably in medical conversations. Again due to the fact that they take no course in English, the item regarding lecture listening has the lowest mean value among all. 
Table 8. The importance of Improving Speaking Skill

\begin{tabular}{lll}
\hline Speaking Sub-Skills & Mean & SD \\
\hline Asking questions in the class & 3.02 & 1.40 \\
Giving oral presentations & 3.09 & 1.41 \\
Discussing with classmates & 3.04 & 1.38 \\
Speaking to a public on medical issues & 3.38 & 1.31 \\
Discussing on medical issues in conferences & 3.81 & 1.28 \\
Speaking for conversational English, such as telephoning, & 4.11 & 1.19 \\
greeting, invitation, etc. & \\
\hline Total $(N=169)$ & \\
\hline
\end{tabular}

Table 8 indicates that the participant medical students give more importance to improve speaking skills for daily conversational English. In addition to this finding, it is pointed out that they want to improve their speaking more to discuss on medical issues in conferences and similarly to speak to a public on medical issues. On the other hand, in-class activities such a discussing with classmates or asking questions in the class are regarded as not significant speaking sub-skills. This finding refers to the same reason that they have no English-medium course.

The last table is about the participants' preference of assessment type in English courses. This is a multiple-choice question and the frequencies and percentages are employed in the data analysis.

Table 9. The preference of Assessment Type

\begin{tabular}{lll}
\hline Assessment Types & $\%$ & F \\
\hline Self-evaluation & 23.7 & 40 \\
Product-oriented evaluation (A series of examinations, quizzes, etc.) & 17.2 & 29 \\
Process-oriented evaluation (Assignments, group works etc.) & 10.7 & 18 \\
No assessment & 42.6 & 72 \\
\hline Total $(N=159)$ & &
\end{tabular}

Table 9 indicates that almost half of the participants do not want to be exposed to any type of assessment for their English courses. This is followed by self-evaluation with a $23.7 \%$ value. The rest of the participants seem to be in favor of product-oriented evaluation type. The least percentage value appear in the process-oriented evaluation type. These findings might be a result of the fact that medical faculty students have very heavy workload and limited time so as to manage assignments, projects and the like in process-oriented evaluation.

\section{Conclusions}

As a part of needs analysis process, the current study aimed at finding out the academic English language needs of first year medical students who are attending advanced English course at the Faculty of Medicine at Karadeniz Technical University. To this end, a structured questionnaire was administered to 169 volunteer medical faculty students. The quantitative data analysis indicate that students' priory purposes in learning English are to be able to interact with others and achieve a score in the related language exams. English learning seem to be more important for the students as prospective medical doctors. Another result is that face to face traditional language classroom is relatively more desirable for the participants. In line with this result, they seem to be against assessment in English courses. However, as compared to product or process evaluation type, self-assessment seems to be more preferable for them. As for the major language skills, speaking is the most important skill to improve and it is followed by listening, reading and writing respectively. The most important speaking sub-skills are speaking to to a public on medical issues, discussing on 
medical issues in conferences, speaking for conversational English. In addition to this, listening to medical audio \& video sources, medical conversations and oral presentations are considered to be the most significant listening sub-skills among all. Reading medical books, articles and manuals are regarded as the most important reading sub-skills while writing articles, projects and taking notes as the most important writing sub-skills.

\section{Suggestions}

Based on the conclusions of the study, the following suggestions might be valuable for the target situation and target stake-holders;

Medical students' awareness regarding the importance of improving English while studying as a medical student should be raised since English should not be just seen as a part of the medical profession but as a part of the medical education. To this end, all stake-holders including department administration, field experts and lecturers in the medicine faculty should contribute to give importance to English throughout the medical education in the faculty by conducting courses in English and raising students' awareness of the status of English in the field

English courses in medicine faculty should focus on major language skills and give priority to communication skills. Besides, the students' awareness about importance of each language skills should be raised and all skills should be integrated in the syllabus.

Medical students' needs should be taken into consideration in designing a medical English course since they seem to be uninformed about e-learning or various assessment types. Accordingly, their barriers towards e-learning environments should be removed. This could be done by preparing some briefings, training or seminars on the related issues.

\section{Limitation of the Study}

Some limitations of the study should be noted here as well. Because of the nature of needs analysis process, a needs analysis should in fact cover all parties including teachers, students, administration and field experts. However, the conclusions of the current study are limited to students' view point as it is indicated in the title and purpose of the study. There are also many sources of information including related literature, students, specialists in the related field, documents, field notes etc. and data gathering tools to reach such sources of information such as journals, observations etc. In this study, a single source of information (students) and data gathering tool (questionnaire) were presented since the study had time limitation.

\section{References}

Akgül, M. (1991). Needs Assessment of Medical Students in ESP Courses at Erciyes University. Unpublished Master Thesis, Bilkent University.

Alagözlü, N. (1994). English Language Needs Assessment of the Students of the Medical Faculty of Cumhuriyet University. Unpublished Master Thesis, Bilkent University.

Basturkmen, H. (2010). Developing courses in English for specific purposes. Basingstoke, UK: Palgrawe/Macmillan

Boztaş, İ. (1987). Identifying Academic English Needs of English Medium Medical Students at Hacettepe University for a Communicative Course Design. Unpublished PhD Thesis, Hacettepe University. 
Diken, Ü. (2006). Gereksinim çözümlemesi kullanılarak uygulanan özel amaçlı dil (İngilizce) ögretimi S.D.Ü. Ĕ̌irdir Meslek Yüksekokulu örneği. Unpublished Master Thesis, Süleyman Demirel University.

Dudley-Evans, T., John, M. J. (1998). Developments in English for specific purposes. Cambridge: Cambridge University Press.

Ertaş, G. (1998). Gazi Üniversitesi Tıp Fakültesi Ortaüstü Ingilizce Dil Öğrencileri İçin Özel Amaçl Modüler Ders Programı. Unpublished PhD Thesis, Gazi University.

Ferguson, G. (2013). English for medical purposes. In Paltridge, B., Starfield, S. Chichester (eds). The Handbook of English for Specific Purposes. Chichester: Wiley-Blackwell.

Hergüner, G. (1990). An Evaluation of the graduate level preparatory course as a needs assessment for a new syllabus desing for basic sciences. Unpublished Master Thesis, Çukurova University.

Gessesse, M. (2009). Identifying students' language needs in private medical colleges in Bahir Dar. Unpublished Master Thesis, Bahir Dar University.

Hutchinson, T., \& Waters, A. (1987). English for specific purposes. Cambridge: Cambridge University Press.

Johns, A. M. (2013). The history of English for specific purpose research. In B. Paltridge \& S. Starfield (Eds). The handbook of English for specific purposes (pp. 5-31). Chichester, West Sussex ; Malden, MA : Wiley-Blackwell.

Kaygan, A. D. (2005). Needs analysis in English for specific purposes (a field study with pilots receiving air traffic terminology training). Unpublished Master Thesis, Başkent University.

Kazar, S. G. (2013). A needs analysis study in terms of the perceptions of the students' learning and target needs at an ESP program: A case study. Unpublished Master Thesis, Yeditepe University.

Master, P. (2005). Research in English for specific purposes. In E. Hinkel (ed.). Handbook of Research in Second Language Teaching and Learning (pp. 99-116). London: Lawrence Erlbaum Associates.

Önder, N. (2012). An Investigation on Turkish Medical Students' EAP Needs. Unpublished Master Thesis, Uludağ University.

Sarı, R. (2003). Gülhane Askeri Tıp Akademisi için bir İngilizce Dil Öğretim Programı Önerisi. Unpublished PhD Thesis, Orta Doğu Teknik University.

Seçen, B. (2001). Makina mühendisliği ve elektrik-elektronik mühendisliği bölümleri ve YADIM arasında özel amaçlı İngilizce öğretimi için işbirliği imkanı. Unpublished Master Thesis, Çukurova University.

Solak, E. (2012). A study of needs analysis at Turkish Gendarmerie in terms of English for specific purposes. The Journal of Language and Linguistic Studies, 8(2), 48-63. http://www.jlls.org/vol8no2/48-63.pdf.

Taşç1, Ç. (2007). An Analysis of Medical Students' English Language Needs. Unpublished Master Thesis, Bilkent University.

Üstünlüoğlu, E. (1994). A Needs assessment of the students of the department of tourism and administration and hotel management at Ballkesir University. Unpublished Master Thesis, Bilkent University.

Yeniçeri, Ö. (2008). Needs assessment of the prep-class students in the Faculty of Medicine at Ondokuz Mayss University. Unpublished Master Thesis, Ondokuz Mayis University.

Yin, R. (1994). Case Study Research: Design and methods. USA: Sage Publication. 